\title{
Russian science chases escape from mediocrity
}

\section{With Putin set to win another presidential term, researchers ask if science will be a priority.}

\section{BY QUIRIN SCHIERMEIER}

A fter letting Russian science languish for years, Vladimir Putin has started to pay more attention. At a meeting of the Council for Science and Education last month, the Russian president promised that science and innovation are now top priorities. The presidential election on 18 March is likely to extend Putin's reign by another six years, but scientists inside and outside Russia wonder whether the country can reclaim its rich science legacy of Soviet times.

"Russia's research system isn't up-to-date any more," says polymer physicist Alexei Khokhlov of Lomonosov State University, a vicepresident of the Russian Academy of Sciences. "It needs a thorough overhaul - otherwise the promises are just words."

Russia has a long way to go to recover its scientific might. Like many of the country's state institutions, its scientific infrastructure and workforce suffered after the break-up of the Soviet Union. Collapsing science budgets and scant salaries during the 1990s prompted thousands of Russian scientists to take up positions abroad, or to leave research altogether.

But there are signs that Russian science is starting to recover. Putin's government has gradually increased investments and public science spending over the past decade, and spending on research and development annually is now around $1 \%$ of gross domestic product (GDP) (see 'Russia rising').

\section{SIGNS OF PROGRESS}

The government earmarked 170 billion roubles (US\$3 billion) for fundamental research and development in 2018, a 25\% rise over last year's basic science budget. The number of scientific papers produced in Russia more than

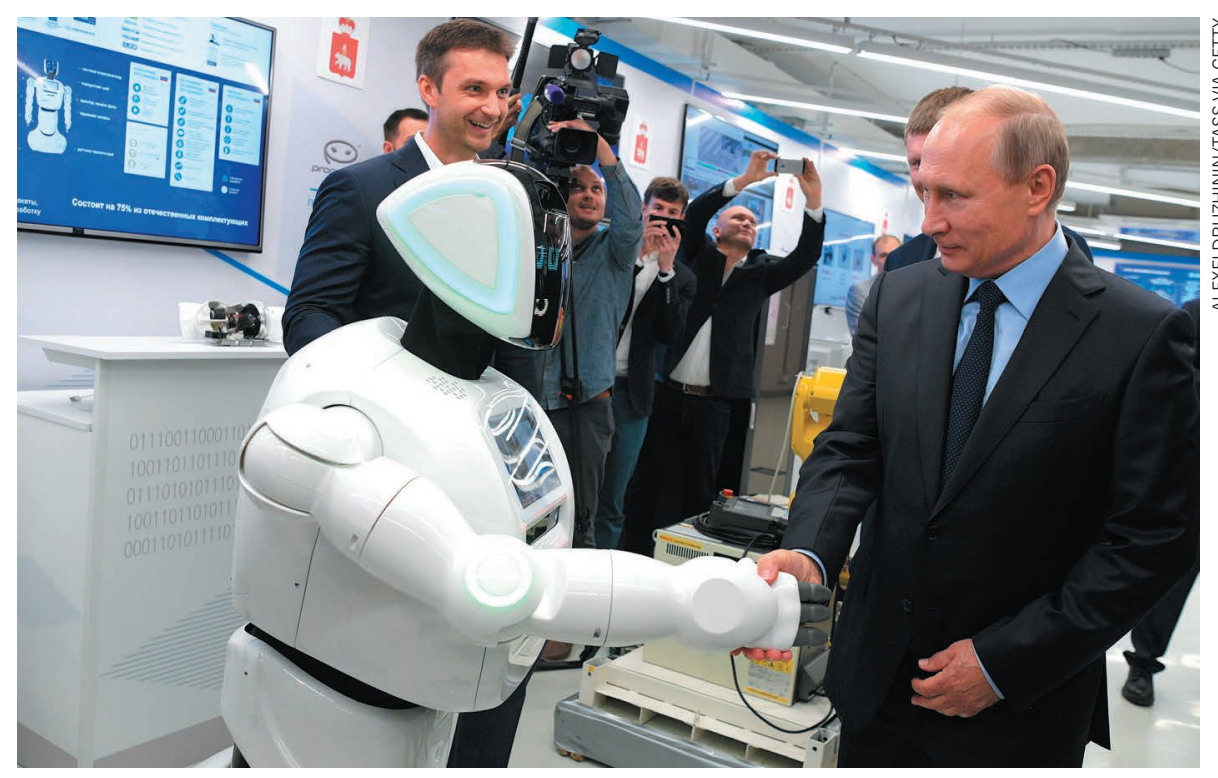

Vladimir Putin shakes hands with a robot built mainly with Russian-made parts.

doubled from 2006 to 2016, outpacing growth in both Brazil and South Korea. Russia is now in the top-ten countries in terms of number of research articles produced - ahead of Canada, Australia and Switzerland - according to statistics released in January by the US National Science Foundation.

"Russian science has greatly suffered, but we are now coming back to a reasonably predictable and well-organized situation," says Artem Oganov, a materials scientist formerly at the State University of New York at Stony Brook who took up a position at the Skolkovo Institute of Science and Technology in 2015. This private research university outside Moscow was created in 2011, in partnership with the Massachusetts Institute of Technology in Cambridge. "I would not have returned if there had been no opportunity to do cutting-edge science here," says Oganov.

For all its progress, Russia's state-funded science still lags behind that of emerging science powers including China, India and South Korea, especially when it comes to translating discoveries into economic gains. Decades of underfunding, excessive state bureaucracy and entrenched opposition to reform within the country's sputtering research institutions are hampering competitiveness, says Khokhlov. "What we need are new ideas, new labs, fresh talent and more freedom and competition."

Many Russian researchers are vexed by state control of their work. An investigation by Nature's news team in 2015 found that many are obliged have their work vetted before they can submit it to foreign journals.

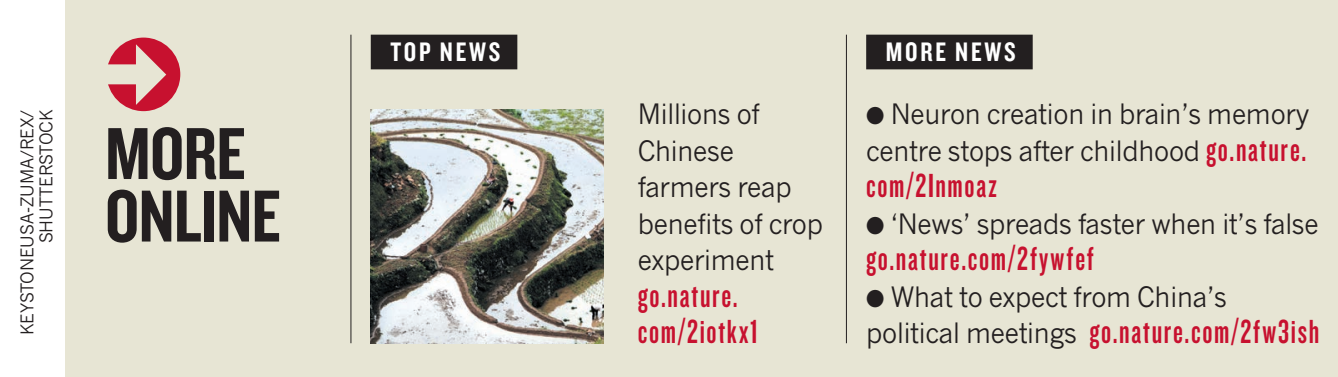

\section{NATURE PODCAST}

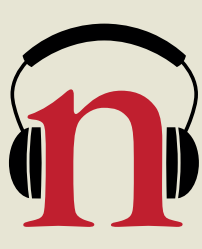

Geoengineering in Antarctica, and increasing the resolution of nuclear magnetic resonance nature. com/nature/podcast 
- Researchers have also been aghast at a crackdown on science-funding charities deemed 'undesirable' foreign agents by the government, including the Dynasty Foundation and branches of the Open Society Foundations, founded by Hungarian-born US philanthropist George Soros.

\section{HOBBLED REFORM}

Putin is eager to reduce Russia's reliance on oil and gas exports. But research-driven efforts to diversify Russia's economy, including a multibillion-rouble nanotechnology initiative launched in 2007 , have not led to new blockbuster products or boosted the economy, say experts in Russian innovation. In 2016, the government launched a national science strategy that listed seven priority areas for state-funded research, including energy, health, agriculture and security. Scientist-led councils oversee funding and management of these efforts, a measure taken to cut down on cronyism by government officials and administrators.

Putin's government also wants to push ahead with reform of the Russian Academy of Sciences, which operates more than 700 institutes in all fields of science. An evaluation completed in January found more than one-quarter of academy institutes to be 'underperforming' in terms of publications, research citations, patents and other metrics. These

\section{RUSSIA RISING}

As Russian science struggles to regain its prestige, emerging science powers such as China are pouring money into research and development.

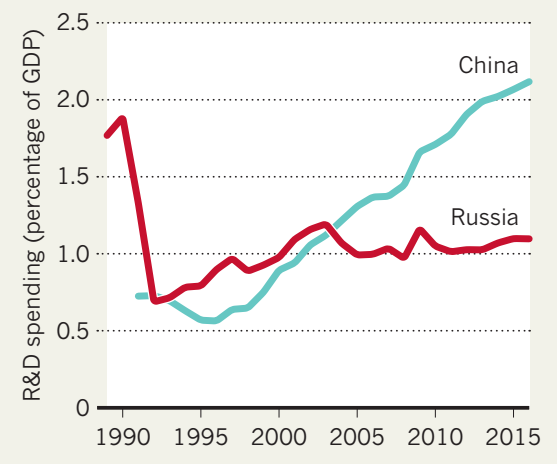

institutes will now be asked to refocus under new leadership, or face closure, says Khokhlov.

The government plans to strengthen neglected university research, too. But, Khokhlov says, aspirations to bring at least 5 Russian universities into the global top 100 by 2020 seem to be unachievable because of scarce funding, poor infrastructure and the inability to attract talented scientists from abroad. Russian scientists will find "incomparably better" opportunities elsewhere, says Konstantin Severinov, a molecular biologist at the Skolkovo Institute. "Money alone cannot build institutions."

Long-simmering institutional problems are not the only drag on Russian science. Sanc- of tions imposed in response to the annexation of Crimea in 2014 led to the suspension of civilian and military science and consultation under the NATO-Russia Council. Putin's top science adviser, Andrei Fursenko, has been banned from entering the United States.

Russian support for Syria's government in the country's ongoing civil war, along with accusations of meddling in democratic elections, has soured relations with the West further. But, so far, geopolitics has not affected Russia's participation in large international research efforts, such as the experimental fusion reactor ITER, under construction in southern France, or the European X-ray free-electron laser in Hamburg, Germany. Neither has it affected the country's involvement in many smaller bilateral collaborations.

But Russian scientists do worry about the future. "Science doesn't take place in a bubble," says Fyodor Kondrashov, a Russian biologist working at the Institute of Science and Technology Austria in Klosterneuburg. "There are substantial barriers to doing competitive science in a politically isolated country. I don't see how that should change as long as Putin holds the reins." - SEEE EDITORIAL P.285 